\title{
PESAN INSTAN MUSLIMAH KELAS MENENGAH BARU: STUDI IDENTITAS ISLAM DI GROUP WHATSAPP "ISLAM"1
}

\author{
Subkhi Ridho
}

\section{Abstrak}

Di Era posmodern, masyarakat memproduksi ribuan pesan dalam jumlah yang sangat besar. Peningkatan tersebut terjadi akibat keberadaan internet yang jangkauannya hingga ke berbagai wilayah. Tulisan ini melakukan observasi mengenai wacana di tiga grup WhatsApp jamaah pengajian yaitu Pengajian Medina, Pengajian Safina, dan Pengajian al-Hijrah yang anggota-anggotanya berasal dari kelompok perempuan kelas menengah Muslim di kota Yogyakarta. Rata-rata anggota jamaah pengajian ini merupakan representasi dari perempuan kelas menengah Muslim yang kuat secara ekonomi dan kalangan terpelajar. Tulisan ini mengelaborasi pandangan mereka dan praktik mereka sebagai Muslim kota di media WhatssApp. Selain itu juga berusaha memahami konstelasi pandangan perempuan kelas menengah Muslim kota kaitannya dengan serangkaian demonstrasi yang menggunakan identitas Islam, seperti Aksi Bela Islam 411, dan 212.

Kata kunci: muslimah, pengajian, WhatsApp, kelas menengah, identitas, representasi, wacana.

1 Paper ini pernah dipresentasikan pada konferensi “Annual International Conference on Islamic Studies" ke-17 pada 20-23 November 2017 di hotel Santika BSD City Serpong Tangerang. 


\section{Pendahuluan}

Menguatnya politik identitas dalam kampanye politik Pilkada DKI tahun 2016 sangat terlihat dalam pesan-pesan yang diproduksi oleh masing-masing tim sukses kandidat. Pesan-pesan tersebut sengaja diproduksi dan menyebar luas di dunia maya. Media yang sangat aktif digunakan ialah WhatsApp. Aplikasi instant message ini memungkinkan perpindahan pesan yang beraneka ragam untuk menggiring keputusan politik tertentu. Dalam kampanye Pilkada DKI tahun lalu, atmosfir kebencian berdasarkan identitas ras, agama dan suku nampak kencang dihembuskan. Tidak hanya di daerah Jakarta yang menjadi tempat kejadian pilihan kepala daerah berlangsung, namun situasi panas tersebut juga merembet pada wilayah yang tidak bersentuhan sekalipun dengan permasalahan tersebut.

Situasi yang seolah-olah genting saat demonstrasi bertajuk Aksi Belas Islam 411, 112 dan berlanjut dengan judul 212 kesemuanya bertema sama, menolak Basuki Tjahaya Purnama alias Ahok karena ia adalah seorang pemimpin non-Muslim. Gerakan yang disponsori Gerakan Nasional Pengawal Fatwa MUI (GNPFMUI) -meskipun MUI membantah tidak ada kaitannya- ini menggunakan dalil agama dan mengklaim berhasil mengumpulkan peserta aksi demo hingga 7,5 juta orang. Meskipun tidak ada penjelasan lanjutan mengenai dasar klaim tersebut dibuat ${ }^{2}$. Demonstrasi mengusung penilaian terhadap Ahok, seorang Gubernur DKI Jakarta, bahwa ia dianggap menghina al-Quran dan telah mencederai perasaan umat Islam karena pidatonya di kepulauan Seribu yang seolah-olah memojokkan al-Quran dan ulama Islam. Isi pidato itu sendiri telah diedit dan diviralkan di media sosial facebook dengan maksud menjegal Ahok seorang petahana yang berpotensi besar memenangkan kompetisi pemilihan kepala daerah.

Selaras dengan kegentingan yang disebarkan di ibu kota Jakarta, diskursus yang sama juga turut didengungkan dalam kajian-kajian agama kelompok urban di Yogyakarta. Dengan kesadaran dan kesengajaan beberapa Masjid yang rutin menyelenggarakan kajian mingguan mengusung tema al-Qur'an surat al-Maidah ayat 51. Topik bahasan ini yang menjadi inti penolakan kelompokkelompok pengajian tersebut terhadap kepemimpinan non-Muslim. Penelitian ini berupaya untuk memahami diskursus Islam yang dibicarakan dalam ruang

2 http://www.bbc.com/indonesia/trensosial-38204802 diakses pada 8 Agustus 2017. Berdasarkan penghitungan dari Muhammad Firmansyah Kasim, mahasiswa doktoral bidang fisika di Universitas Oxford, Inggris, secara matematis melihat besaran wilayah yang dijadikan aksi demonstrasi maka jumlah yang mendekati kebenaran sekitar 500 ribuan peserta aksi. 
instant messages khususnya WhatsApp yang menjadi media berkomunikasi utama kelompok pengajian khususnya pada kelompok pengajian ibu-ibu kelas menengah, di wilayah urban Yogyakarta. Tiga kelompok kajian dan pengajian dipilih peneliti diantaranya Pengajian Medina, Pengajian al-Hijrah dan Pengajian Safina. Kelompok pengajian ini beranggotakan ibu-ibu dalam rentang usia 30 50 tahun. Mereka memiliki latar belakang pendidikan minimal sarjana, ada yang bekerja sebagai guru, pengusaha lokal Jogja dan ibu rumah tangga serta sebagian memiliki account media sosial.

Mereka berada pada segmen kelas menengah Muslim yang dapat ditandai dengan indikator antara lain yakni anak-anak mereka mengenyam pendidikan di sekolah swasta Islam terkemuka di kota Jogja yang tidak dapat dianggap murah. Dua dari tiga pengajian ini diikuti karena aktivitas mereka yang sering bertemu setiap hari ketika menunggui anak mereka pulang sekolah. Masjid di sekitar sekolah sang anak digunakan untuk mengelola waktu dan sumberdaya mereka yang berlimpah (ekonomi, tenaga dan pemikiran) dengan berkumpul mengkaji Al-Quran dan Hadist secara tematik. Pertemuan rutin dilakukan satu minggu sekali dan setelahnya kelompok besar (berjumlah lebih kurang 250 jamaah) akan secara alamiah menjadi kelompok-kelompok kecil dengan meneruskan aktivitas kumpul-kumpul sesuai ketertarikan masing-masing anggota. Ada yang melanjutkan dengan rapat pengurus pengajian, merencanakan bakti sosial bersama, berdiskusi tema kajian sebulan ke depan, membentuk formasi arisan dalam kelompok kecil, transaksi jual beli barang atau memilih pulang karena sejalan dengan berakhirnya jam sekolah anak-anak mereka.

Satu kelompok yang sedikit berbeda dengan dua kelompok lainnya adalah Pengajian Medina. Kelompok ini membuat grup online melalui instant messenger dengan insiasi awal di Jakarta pada tahun 2014, meskipun mereka mengklaim komunitas ini telah ada sejak 2009 dengan menggunakan metode pesan singkat pendek atau sms. Aktivitas ini kemudian dikelola pada kelompok-kelompok lebih kecil di daerah-daerah. Di Yogyakarta komunitas ini mayoritas diikuti oleh ibuibu berumur 40-55 tahun dan berprofesi guru. Salah satu alasan mengapa guru nampak dominan dalam latar belakang pekerjaan anggota kelompok khususnya di Yogyakarta, karena admin kelompok yang juga dikenal dengan singkatan WAG Medina ini berprofesi sebagai tata usaha administrasi di kampus keguruan di Yogyakarta. Ia merekrut dan mengajak teman-teman seprofesi dan almamater tempat mereka dulu bersama-sama bersekolah sebagai calon guru. Penggunaan grup WhatsApp menjadi media lalu lintas yang signifikan dalam menyebarkan informasi dalam kelompok-kelompok ini. 
Media sosial yang sangat populer di dunia di antaranya adalah Facebook, Twitter dan LinkedIn yang berfokus pada situs jaringan sosial (social networking sites). Instagram, Snapchat dan YouTube yang masuk pada kategori media sosial berbagi citra visual (media sharing networks). Media sosial berbentuk forum diskusi online di Indonesia terkenal dengan nama Kaskus, di belahan negara lain ada reddit, Quora dan Digg. Ada pula jenis lain seperti Pinterest dan Flipboard yang dapat menandai dan mengumpulkan gambar sehingga berlaku seperti kliping (bookmarking and content curation networks). Media sosial lain berfungsi sebagai jaringan ulasan produk dan jasa oleh konsumen, yang terkenal di dunia seperti Yelp, Zomato dan TripAdvisor. Ada pula media sosial yang berfungsi untuk tujuan memublikasikan, mencari dan mengomentari konten online seperti Tumblr, WordPress dan Medium. Sedangkan media sosial yang berfokus pada pertukaran pesan cepat dikenal dengan beberapa istilah yaitu instant messenger dan chat online application.

Pergeseran situasi bermedia ini mengakibatkan efek budaya literasi dan visual dalam masyarakat dunia, tidak terkecuali di Indonesia. Hal ini berlaku pula untuk perempuan yang telah menyandang status ibu, Muslimah, dan berada pada kelas menengah. Interseksi identitas inilah yang peneliti analisis untuk melihat bagaimana diskursus yang terjalin berkaitan ketertarikan mereka dalam aktivitas pengajian yang dapat direlasikan dengan isu yang sedang terjadi kekinian. Identitas jamaah pengajian ibu-ibu kelas menengah Muslim ini menguat karena konstruksi ataupun dorongan dari wahyu agama (religious revelations) Islam ${ }^{3}$. Pada waktu penelitian ini dilakukan periode bulan AgustusSeptember 2017, isu bangkitnya ideologi PKI (Partai Komunis Indonesia) menjadi hal yang nampak masif diperbincangkan.

Peneliti tidak hendak melihat fenomena demo Aksi Bela Islam secara khusus, karena peristiwa tersebut sudah terjadi dan akan sulit untuk melakukan observasi dan analisis. Namun peristiwa tersebut hanya akan menjadi pijakan konstruksi berpikir melihat situasi masyarakat Indonesia khususnya kaum ibu, Muslimah, dan kelas menengah dalam merespon persoalan bangsa khususnya mengenai diskursus toleransi dan kebinekaan yang menjadi isu utama dalam pemerintahan Jokowi-JK. Maka penelitian ini akan berfokus pada pertanyaan:

1. Diskursus Islam seperti apa yang ada dalam media instant message WhatsApp group kelompok-kelompok pengajian ini?

2. Bagaimana posisi masing-masing kelompok merespon persoalan sosial, politik, budaya dan agama yang terjadi di Indonesia, khususnya

3 Manuel Castells, The Power of Identity, USA: Blackwell Publishers Inc, 1997, hlm. 7. 
mengenai menguatnya identitas agama [Islam] dalam kehidupan bernegara setelah peristiwa demo Aksi Bela Islam?

Dua pertanyaan ini penting diajukan untuk dapat mengetahui praktik bermedia yang dilakukan kelompok-kelompok pengajian. Sehingga dapat merefleksikan pemahaman, posisi dan nilai-nilai yang hidup dan disebarkan oleh kelompok kajian keagamaan, khususnya di kalangan kelas menengah Muslimah urban di Yogyakarta yang direpresentasikan melalui jamaah-jamaah pengajian.

\section{Metode dan Kerangka Teoritis}

Kajian ini tidak dimaksudkan sebagai kajian holistik namun lebih menekankan representatif. Dengan memilih dan memahami data dalam rentang bulan Agustus-September 2017 peneliti memperoleh berbagai rekaman pembicaraan kelompok kajian dan pengajian yang dapat merefleksikan ideologi dan posisi keagamaan masing-masing kelompok serta perspektif mereka dalam melihat situasi sosial-politik mutakhir di tanah air. Untuk mendapatkan data tersebut peneliti melakukan observasi langsung dengan mengamati, terlibat dalam aktivitas pengajian, dan melihat interaksi langsung dalam kelompok. Selain itu peneliti masuk dan mengikuti kelompok masing-masing pengajian, mengikuti percakapan dan pesan apa saja yang dibicarakan dalam grup instant message tersebut. Melalui pendekatan kepada pengelola WhatsApp Group (WAG) peneliti berhasil masuk ke dalam grup tersebut selama lebih kurang dua bulan lamanya.

Selain melakukan observasi, peneliti menggunakan metode analisis wacana virtual ethnography ${ }^{4}$ dengan melihat kalimat dan bahasa yang digunakan akan diamati untuk mendapatkan deskripsi mengenai hal yang menjadi obyek penelitian. Pilihan gambar, kata, frase, kalimat maupun penggunaan bahasa dalam WAG untuk selanjutnya dianalisis dengan pendekatan analisis wacana. Proses selanjutnya ialah analisis diskursif, yaitu tahapan ketika sebuah teks baik tulisan maupun visual (gambar) ditampilkan dalam sebuah media maka akan terlihat tujuan mengapa teks tersebut dipilih untuk ditampilkan. Tahapan terakhir adalah eksplanasi yaitu penjabaran analisis yang memberikan jawaban dan penjelasan mengapa pilihan-pilihan teks tersebut hadir, latar belakang individu dalam kelompok, yang menghasilkan pemaknaan. Sehingga menghadirkan konsekuensi atas interpretasi teks yang seperti apa. Tahap tiga akan memunculkan analisis yang dapat melihat diskursus yang mewarnai dalam setiap kelompok.

4 Christine Hine, Virtual Ethnography, London: Sage, 2000. HIm. 7. 
Kerangka teoritis dalam penelitian ini berpijak pada penjelasan media baru dapat memaksimalkan partisipasi warga dalam kehidupan politik dan sekaligus menjadi alat politik ${ }^{5}$. Artikulasi politik dapat didefinisikan sebagai sejauh mana warga negara dan kelompok masyarakat dapat memengaruhi kebijakan melalui institusi demokrasi. Tidak hanya bersandar pada sistem politik yang statis dan institusi yang stagnan, sejak hadirnya media sosial artikulasi politik dapat hadir dengan berbagai ekspresi ${ }^{6}$. Misalnya melalui meme yang disebarkan, tulisantulisan berupa ajakan atas gerakan tertentu, kata-kata mutiara berupa motivasi, atau simbol-simbol yang mewakili sikap politik yang spesifik. Hal ini dapat dilakukan melalui media sosial yang mendorong komunitas virtual sebagai wadah untuk berpolitik, atau sebaliknya berpolitik menggunakan media sosial.

Mengapa demikian? Karena internet juga dapat meningkatkan kapital sosial (social capital) dengan adanya saling tukar informasi antarpenggunanya? Pertukaran ini turut membentuk persepsi, sikap dan pilihan-pilihan politik baik secara langsung atau tidak, apalagi WAG digunakan dalam relasi di ruang paling pribadi dalam aktivitas keseharian mereka. Meskipun dalam setiap kelompok akan selalu menunjukkan kekhasan dalam berkomunikasi. Baik melalui pilihan kata, kalimat, gambar dan cara pandang antar individu merespon realitas sosial. Tidak dapat terelakkan keadaan ini terjadi karena pegeseran bentuk komunikasi dari komunikasi suara (voice communication) menjadi komunikasi data (data communication) hal ini terutama terjadi pada kaum muda dan profesional ${ }^{8}$.

Indikator kelas menengah diambil dari data Asian Development Bank (ADB) yang menetapkan pengeluaran perkapita sebagai acuannya yaitu 2-20 US\$ perhari. Kategori kelas menengah ini dibagi lagi menjadi tiga. Pertama, disebut sebagai kelas menengah bawah yaitu yang pengeluaran perkapitanya hanya 2-4 US\$ perhari. Kedua, kelas menengah tengah, yakni mereka yang pengeluaran perkapitanya 5-10 US\$ perhari. Ketiga, kelas menengah atas, mereka yang pengeluaran perkapitanya 11-20 US $\$$ perhari. Indikator tersebut juga digunakan oleh World Bank. Dimana di Indonesia saat ini berdasarkan data dua lembaga

\footnotetext{
5 Sparks, C. (2001) 'The Internet and the Global Public Sphere', dalam L.W. Bennett and R.M. Entman (eds) Mediated Politics: Communication in the Future of Democracy, Cambridge: Cambridge University Press. HIm. 75-95.

6 Ashwini Chhatre. Political Articulation and Accountability in Decentralisation: Theory and Evidence from India. Dalam http://unpan1.un.org/intradoc/groups/public/documents/apcity/ unpan034369.pdf diakses pada 11 November 2017. HIm 15-17.

7 Howard Rheingold, 2000. The Virtual Community: Homesteading on the Electronic Frontier (2nd Edition). Cambridge, Massachusetts: MIT Press.

8 Purbo, Onno W, dan Hartanto.(2002). E-Learning berbasis PHP dan MySQL, Penerbit Elex Media Komputindo, Jakarta.
} 
keuangan internasional menyebutkan terdapat 56\% jumlah kelas menengah dari total penduduk Indonesia, yaitu sekitar 130 juta jiwa pada 2011 lalu. Data ini sangat mungkin bertambah mengingat perekonomian nasional kita mengalami tren kenaikan meskipun di dua tahun awal pemerintahan Jokowi-JK sempat menurun -yaitu 2014-2016- dibanding pemerintahan sebelumnya.

\section{Pembahasan}

\section{WhatsApp Group sebagai Ruang Politik Identitas Islam Kontemporer}

Menurut data The Asian Parent yang melakukan survey (2017) pada $1.070 \mathrm{ibu}$ yang berada di kota Jakarta, Surabaya, Medan dan Bandung di antara kesemua chat instant yang tumbuh di Indonesia WhatsApp adalah aplikasi terpopuler saat ini. Berurutan kemudian adalah FB Messenger, BBM dan Line. Tingginya penggunaan aplikasi komunikasi ini menjadi menarik untuk memahami praktik konsumsi dan produksi pesan yang ada di dalamnya. Merujuk pada Newman \& Levy (2014) aplikasi chat instant ini menjadi jaringan utama dalam penyebaran berita dan jaringan pesan di beberapa negara. Hal ini sejalan dengan riset yang dirilis oleh Reuters Insititute (2016) yang menunjukkan data 50.000 orang di 26 negara, media sosial telah mengantikan televisi sebagai sumber berita khususnya bagi anak muda. Medium ini memastikan kemudahan percakapan yang intim antara dua individu dan kelompok yang lebih besar.

Kegunaan WhatsApp juga mencakup berbagai variasi, seperti pesan singkat, melampirkan gambar, file audio dan video dan link alamat website. Hal ini yang menjadikan aplikasi ini menjadi sangat populer dengan mendapatkan 350 juta pengguna, dan memiliki rangking tertinggi aplikasi yang di unggah di 127 negara seluruh dunia (Cohavi, 2013). Begitu pula di Indonesia, berbagai informasi yang awalnya disebarkan pada media arus utama, saat ini mulai tertandingi dengan kecepatan pesan di genggaman tangan. Konsekuensi yang lahir adalah banyaknya berita yang belum tentu benar dalam hitungan detik sudah berpindah ke tangan berbagai pihak dengan mekanisme berbagi pesan. Viralnya berita-berita hoax yang mengadu domba, menyesatkan dan bersumber pada kebencian menjadi lebih mudah dibagikan karena mudahnya akses ini ditangan masyarakat luas.

Dalam artikel media online Calcalist (Tzuk, 2013) bahkan menengarai setidaknya 31 juta pesan dikirimkan setiap hari melalui aplikasi ini. Begitu pula yang terjadi di dalam grup WhatsApp masing-masing kelompok pengajian yang peneliti 


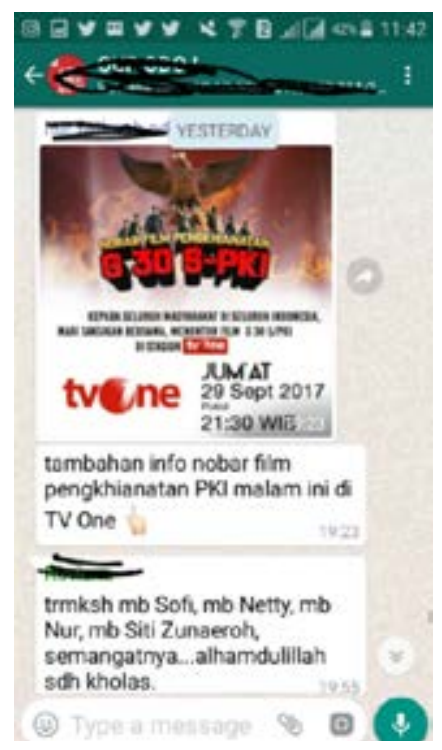

Gambar 13. WAG Medina amati. Bahkan kelompok pengajian Medina memiliki dua grup sekaligus. Bernama WAG Medina sebagai wahana mengobrol aktivitas para anggotanya, obrolan dapat mengenai apapun. Seperti dalam screen shoot Gambar 13..

Gambar 13 menjelaskan aktivitas salah satu anggota membagikan informasi mengenai acara menonton bareng film G30S/PKI di stasiun televisi TV One. Meskipun beberapa anggota grup memiliki ketertarikan terhadap isu politik tertentu, namun mayoritas anggota kelompok yang lain terlihat enggan untuk menanggapinya. Menurut pengakuan salah satu anggota yang peneliti wawancarai yaitu ibu Sri, ia menjelaskan kelompok yang ia ikuti ini sering menghindari pembicaraan dan perdebatan isu-isu politik yang sedang ramai. Soal PKI misalnya, mereka mayoritas memilih untuk tidak membicarakannya dalam WAG.

Alasan mereka adalah tidak semua orang menyukai isu politik, dan dapat saja berseberangan dengan pemikiran anggota satu dengan lainnya. Menariknya ibu Sri mengungkapkan ia sangat berkeyakinan mayoritas anggota kelompok ini adalah pendukung demo gerakan Aksi Bela Islam dan pro terhadap pandangan Orde Baru yang mengonstruksi sejarah dalang pembunuhan para jenderal tahun 1965 adalah Partai Komunis Indonesia. Meskipun mayoritas enggan berkomentar namun 2-3 orang anggota aktif membagikan informasi seputar berita-berita anti Syiah, isu Palestina dan Rohingnya. Pilihan gambar ini menarik dilihat sebagai bagian dari anggota WAG untuk melakuan proses politik. Meskipun mayoritas anggota tetap kelompok WAG ini berupaya untuk menghindari komunikasi yang saling menghakimi satu sama lain, dengan berada di jalur diam tapi emas.

Sementara itu grup kedua bernama WAG Muslimah Medina G3188 F43 yang merupakan kependekan dari nama no grup 3188 dari seluruh grup Medina di Indonesia, sedangkan F43 berarti Fasil (Forumnya Para Admin untuk Bersilaturahim). Grup Muslimah Medina digunakan sebagai grup laporan tilawah $1 \mathrm{Juz}$ setiap harinya. Mereka memiliki misi dan visi seperti yang tercantum di dalam website mereka yaitu "membudayakan (terbiasakan) tilawah sehari satu juz di seluruh lapisan masyarakat Muslim dari berbagai kalangan”. Informasi mengenai hasil bacaan tersebut dilaporkan setelah para anggota menunaikan salat wajib di masing-masing waktu, dan menyempatkan 
membaca ayat Al-Quran setelahnya. Screen shoot laporan bacaan dari anggota menggunakan simbol-simbol yang terdapat di WAG dapat dilihat dalam Gambar 14 berikut ini
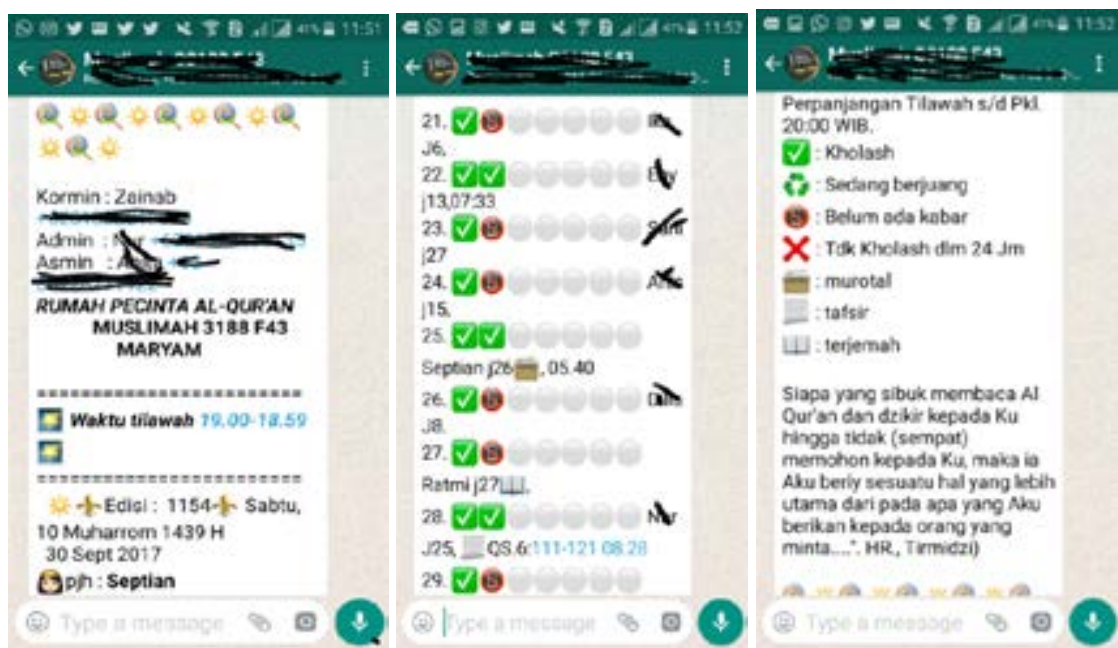

Gambar 14. WAG Muslimah G3188 F43

Anggotanya tersebar di seluruh Indonesia, grup ini dibuat untuk memotivasi anggotanya untuk dapat menyelesaikan 1 juz setiap hari. Masing-masing anggota telah diberi tugas oleh admin grup untuk membaca bagian masing-masing, kemudian melakukan pelaporan di dalam grup. Kesemua ayat dan juz yang berhasil ditunaikan untuk dibaca akan diakumulasi dengan anggota yang lain dan motivasi inilah yang digunakan untuk mencapai target khatam Al-Quran bersama-sama. Dalam kurun waktu seminggu laporan ini diakumulasikan dan menjadi laporan admin kepada anggota. Menariknya kelompok ini selain menggunakan emoticon, simbol populer di dalam aplikasi WhatsApp juga menggunakan bahasa-bahasa Arab seperti kholash yang berarti "telah dilakukan/ sudah selesai dilakukan”, murotal "baca dengan tartil/membaca dengan huruf yang benar", tilawah berarti "membaca Al-Quran dengan baik, indah, dan benar sesuai dengan aturan dan kaidah tata bahasa Arab”.

Kelompok pengajian kedua ialah Al-Hijrah yang aktivitas pengajian ini berada di masjid bersejarah di kota Yogyakarta, yaitu Masjid Syuhada. Pengajian ini di bawah otoritas pengawasan Yayasan Masjid Syuhada (YASMA) yang juga memiliki sekolah Islam dalam lingkungan masjid. Nama Al-Hijrah dipilih karena sesuai dengan filosofi "mari kita berpindah dari yang baik menuju yang lebih baik, dari yang kurang baik menuju ke yang baik”. Berdiri sejak awal tahun 
1986 pengajian ini dimotori oleh seorang wali murid SD Syuhada, ia adalah istri tokoh Reformasi nasional yang pada era tersebut sedang menyekolahkan anak-anaknya di lingkungan masjid. Karena di bawah pengawasan yayasan dan Keraton Yogyakarta masjid ini berusaha untuk tidak berafiliasi dengan ormas manapun yang ada di Indonesia. Hal ini nampak dipegang teguh oleh ketua pengajian sampai saat ini, meskipun ia mengaku terjadi tarik menarik yang kuat di antara kepentingan beberapa kelompok Islam yang juga pernah berusaha "masuk" untuk menundukkan kelompok pengajiannya. Namun usaha kooptasi dari salah satu golongan Islam terhadap kelompok jamaah pengajian masjid Syuhada di kota Yogyakarta ini tidak berhasil.

Program pengajian al-Hijrah antara lain, pengajian rutin setiap Selasa, Rabu, dan Jumat. Masing-masing pertemuan memiliki penekanan dalam isi materi, Selasa untuk tahsin (belajar membaca al-Quran dengan benar), hari Rabu berisi pengajian tematik yang dapat disesuaikan dengan usulan anggota pengajian dan melihat isu-isu terkini di masyarakat, sedangkan untuk hari Jumat berisi tafsir alQuran. Menurut pengakuan ibu Farchatul Kifyati selaku ketua pengajian setiap pertemuan berlangsung memiliki anggotanya sendiri-sendiri, jadi dapat saja ibuibu yang masuk dalam pengajian hari Selasa tidak tertarik dalam pengajian hari Rabu, dan Jumat, begitu pula sebaliknya. Sejauh ini jamaah ibu-ibu terbanyak hadir saat pengajian di hari Selasa.

Peneliti berusaha untuk menggali informasi terkait dengan aksi Bela Islam 411 dan 212. Karena situasi sudah berlalu pada rentang waktu akhir 2016 dan awal 2017 lalu, maka peneliti mencari tahu sikap-sikap yang muncul dalam kelompok ini melalui beliau. Menurut pengakuannya memang terjadi pembicaraan dalam kelompok jamaah, baik yang mendukung aksi maupun yang tidak setuju aksi. Meskipun jumlah yang mendukung aksi lebih kecil dibanding yang tidak mendukung, namun lebih kencang dalam menyuarakan atau dalam istilah ia menyebutnya "lebih vocal". Keseharian ibu Farcha adalah ibu rumah tangga dengan 4 orang anak, anak pertama dan kedua telah menikah, anak ketiga sedang merintis karirnya dan anak keempat akhir tahun ini akan menyelesaikan sekolahnya di London School of Economic United Kingdom dengan biaya penuh dari suami ibu Farcha. Secara sosial ekonomi memperlihatkan ibu Farcha berada pada kelas menengah atas, yang kuat secara sumber ekonomi, sehingga tenaga dan pikiran serta waktunya dapat digunakan untuk mengelola kelompok-kelompok sosial keagamaan yang ia ikuti dengan maksimal.

Dalam pembicaraan di WAG jamaah al-Hijrah mengenai Pilkada DKI, terdapat sekian jamaah yang setuju Ahok menjadi pemimpin Jakarta namun ada yang 
terang-terangan menolaknya dengan alasan karena nonmuslim alias bukan beragama Islam. Alasan tersebut lebih didasarkan pada satu ayat di dalam alQuran, yaitu surat Al-Maidah ayat 51. Setelah ditelusuri berdasarkan asal usul turunnya ayat tersebut, sesungguhnya tidak ada hubungannya dengan persoalan pemimpin pemerintahan, karena turunnya ayat tersebut terkait dengan situasi peperangan pada zaman Rasulullah SAW. Perdebatan pandangan ini terjadi sebentar di grup WAG, kalaupun kemudian terjadi adu pendapatyang lebih serius biasanya saat pertemuan pengajian offline berlangsung, melalui pembicaraan informal setelah pengajian berakhir. Dalam sepanjang wawancara peneliti juga mendapatkan informasi bahwa secara pribadi ibu Farcha sesungguhnya mengakui kinerja Ahok, bahkan menyayangkan sampai terjadinya Aksi Bela Islam dengan berakhirnya vonis penjara untuknya. Terbukanya pola pikir ini dibarengi dengan undangan kegiatan masjid yang ia bagikan kepada anggota WAG Al-Hijrah berikut ini:
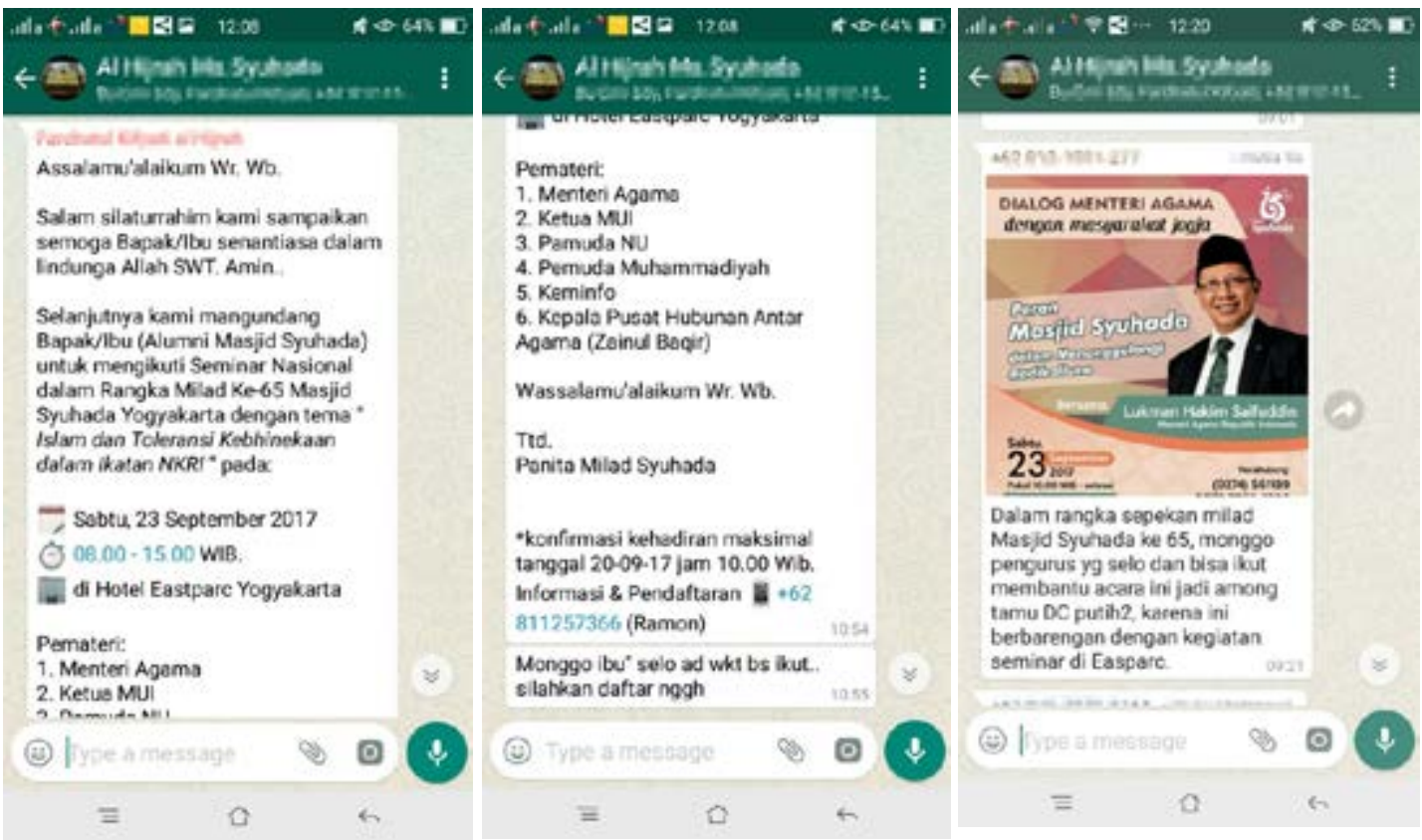

Gambar 15. WAG Al-Hijrah informasi mengenai seminar nasional toleransi dan kebinekaan.

Namun di pernyataan yang lain, secara tegas pula ia menolak apabila Ahok yang seorang Kristiani menjadi Gubernur ibu kota Jakarta. Pernyataan ini merupakan sikap ambivalensi yang mengakui kinerja dan keprihatinan beliau terhadap sikap-sikap diskriminatif di kalangan masyarakat Muslim terhadap ras minoritas di Indonesia, namun di lain pihak juga tidak menginginkan seorang 
Kristen terpilih. Meskipun ia juga mengakui Anies Baswedan bukan calon yang hendak dipilihnya dalam kontestasi demokrasi tersebut jika ia memiliki hak pilih. Artinya identitas Islam itu bukan dijadikan acuan utama, namun lebih pada karakter Muslim yang melekat pada sosok seorang kandidat. Sejalan dengan konsep Civil Islam menurut Robert W. Hefner (2000) bahwa kelas menengah muslim Indonesia sangat mendukung sistem demokrasi dimana ia memiliki nilai-nilai sebagai berikut; menunjung tinggi kesetaraan, kebebasan, keadaban, toleran, inklusif, pluralis. Namun berdasarkan hasil dari observasi ini, kelas menengah muslim nampaknya masih setengah hati dalam menerima prinsip-prinsip demokrasi. Hal ini terlihat dari keenganan kelas menengah Muslim dalam memilih pemimpin politik yang berbeda agama.

Kelompok pengajian ketiga ialah Safina. Diselenggarakan setiap hari selasa kelompok pengajian ini didirikan pada awal tahun 2000-an. Beranggotakan kurang lebih 114 orang, sistem keanggotaan kelompok ini sama dengan al-Hijrah yang diinisiasi oleh wali murid sekolah Islam swasta ternama di Yogyakarta. Memiliki jamaah yang loyal dengan kelompok, bahkan ada anggota dan pengurus pengajian ini yang aktif melakukan kegiatan meskipun anakanak mereka telah lulus sekolah dari tempat pengajian diselenggarakan. Dalam wawancara peneliti mendapatkan informasi bahwa pendiri pengajian ini adalah ibu Intan yang sebelumnya mengikuti pengajian al-Hijrah, namun ia merasa tidak menemukan kecocokan dalam majelis taklim tersebut. Pengajian Safina berusaha membuat pengajian yang berbeda dengan tidak pernah mengunggah dan memamerkan kegiatan bakti sosial mereka di media sosial. Masjid sekolah sang anak dimanfaatkan untuk berkumpul dengan berbagai kajian keagamaan. Ijin dari pihak sekolah juga didapatkan dengan komite sekolah yang juga aktif mendukung kegiatan pengajian. Ia lalu menjelaskan dalam pengajian Safina semua kalangan kelas sosial dapat masuk dan bergabung.

Dalam postingan WAG ustadz-ustadz yang sering dijadikan patron dalam kegiatan dakwah Islam mereka diantaranya Bachtiar Nasir dan AA' Gym. Dua nama ini adalah penggagas dan pendukung gerakan demonstrasi Aksi Bela Islam 4 November 2016 dan 2 Desember 2016. Ia menjadi ketua Gerakan Nasional Pengawal Fatwa Majelis Ulama Indonesia (GNPF-MUI) yang hingga saat ini sering menggunakan agama sebagai alat politik untuk menyerang pemerintahan Joko Widodo. Berikut WAG kelompok pengajian Safina yang membagikan informasi kajian agama yang akan berlangsung di Masjid Jogokaryan Yogyakarta. 

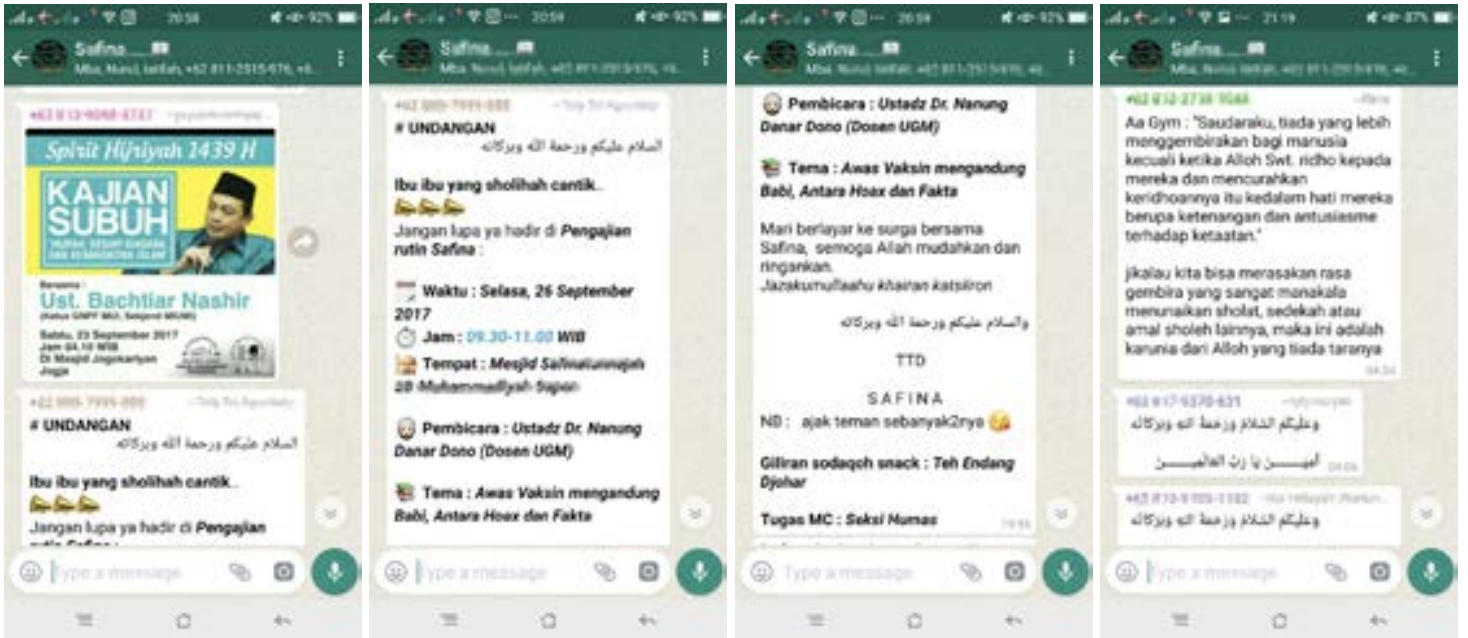

Gambar 16. WAG Pengajian Safina

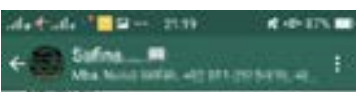

Mari tol 30 September 2017 bin

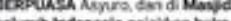

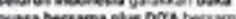
ife keselomosah indonesie.

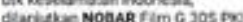
cetegoimens saran fanglims the

Semoga Alloh meryelomathan bamgia in cavi sertua ketuvian jehat aserg asing das porro perotiand

bergas:

Wolohe nam

\section{cotumarte in}

Secrarg wantu gemik hom meringal Don dimakimikan menisgaskan ki hure menolik Dan vetap mengali bevan wh mendetkes maikinns kerrbat.

Q 0

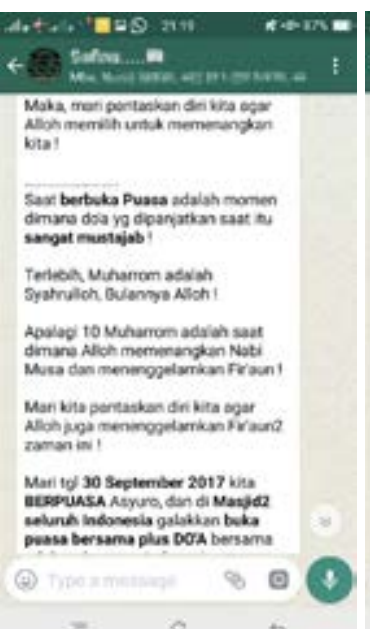

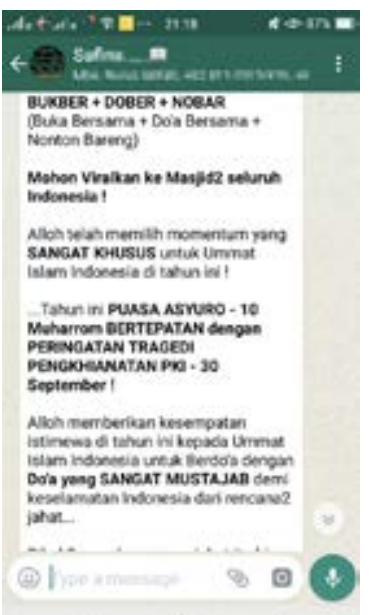
e

Gambar 17. WAG Pengajian Safina yang membagi pesan viral ajakan untuk menggunakan masjid sebagai tempat nonton bareng film G30S/PKI versi Orde Baru

Kesimpulan yang peneliti dapatkan saat ikut langsung dalam aktivitas pengajian ini adalah, materi-materi yang diberikan cenderung lebih "galak" daripada kelompok pengajian Al-Hijrah. Salah satu penceramah yang diundang pada kesempatan selasa 12 September 2017 adalah Imam Wicaksono, Lc., MA. Ia memberikan penjelasan bahwa pentingnya mencintai saudara seiman. Ia menyatakan "Ini adalah bentuk keimanan yang ada pada diri seseorang, untuk itu memberi pertolongan dan menyayangi saudara seiman adalah kewajiban”. Ia juga menerangkan kasus Rohingnya dan Palestina merupaan 
bukti paling kuat bagaimana kelompok-kelompok "kafir" tidak menyukai kebangkitan Islam. Untuk itulah persaudaraan penting untuk mendahulukan kepentingan Islam. Menurut ibu Intan selaku ketua kelompok pengajian ini, penceramah-penceramah yang dipilih sesuai dengan afiliasi kelompok ini yaitu Muhammadiyah. Begitu pula dengan postingan-postingan yang dimunculkan untuk dibagikan dalam WAG meskipun tidak semua, namun sebagian besar adalah hasil dari referensi ormas yang didirikan KH. Ahmad Dahlan ini. Menariknya aktivitas Masjid Jogokaryan juga sangat sering diposting dalam WAG pengajian Safina meskipun mereka merasa tidak memiliki afiliasi nyata dengan kelompok kajian di sana. Agaknya popularitas Masjid Jogokaryan memang sering dijadikan rujukan sebagian besar kelompok pengajian di Yogyakarta.

\section{Kelas Menengah dan Ekspresi Kesalehan di Instant Message WhatsApp Group}

Jaringan internet memiliki implikasi yang signifikan dalam persoalan perilaku masyarakat. Berbagai kemudahan hidup dihasilkan bersamaan dengan meningkatnya kualitas teknologi dalam kehidupan sehari-hari. Selain itu media baru menjanjikan kecepatan dalam mengonsumsi dan memproduksi pesan. Dengan cara menekan satu tombol retweet (pengulangan kicauan), repost (pengulangan unggahan), atau re-share (pengulangan berbagi) maka pesanpesan dapat viral dan memperoleh perhatian publik. Kemudahan komunikasi ini menjadi bagian dari perkembangan teknologi di dunia. Masyarakat menjadi suatu keterhubungan jaringan yang menempatkan informasi menjadi hal yang utama dan berelasi dengan ekspresi kesalehan. Seperti di Indonesia sebagai negara yang mayoritas pemeluk agama Islam memiliki berbagai varian Islam yang hidup di dalamnya. Interaksi antargolongan dan varian Islam ini dipengaruhi oleh segmen kelas dan berkaitan dengan cara menampilkan identitas diri mereka.

Kelompok al-Hijrah misalkan secara aktif meneguhkan identitas kelompok melalui pakaian. Ekspresi ini dilakukan saat terjadi kegiatan bersama-sama. Seragam menjadi penanda dan petanda apakah individu tersebut dapat dikatakan masuk dalam kelompok (in-group) atau keluar dari kelompok (outgroup). Peneguhan tersebut tidak hanya terjadi dalam ruang online (dalam interaksi di WAG) namun juga saat interaksi offline. Gambar berikut ini menjelaskan bagaimana identitas pakaian yang seragam sangat penting dalam keberlangsungan eksistensi anggota kelompok ketika melakukan acara di luar maupun di dalam lingkungan pengajian. Seperti yang nampak dalam percakapan anggota kelompok dalam acara bakti Sosial dalam rangka Milad ke65 masjid Syuhada dan Milad Pengajian al-Hijrah ke-31 berikut ini: 


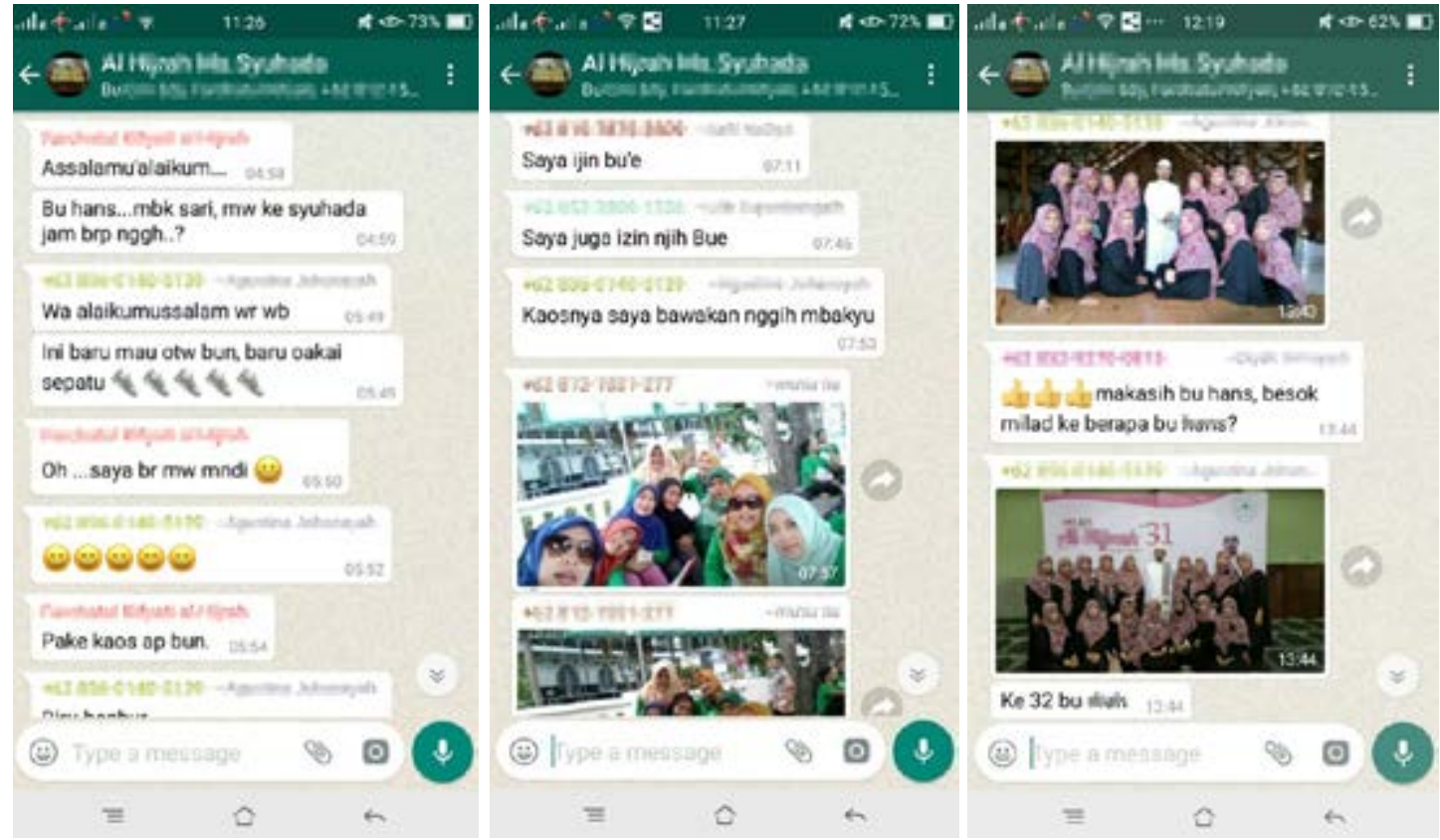

Gambar 18. Percakapan di WAG Al-Hijrah saat persiapan bakti sosial dan foto-foto anggota yang menggunakan seragam

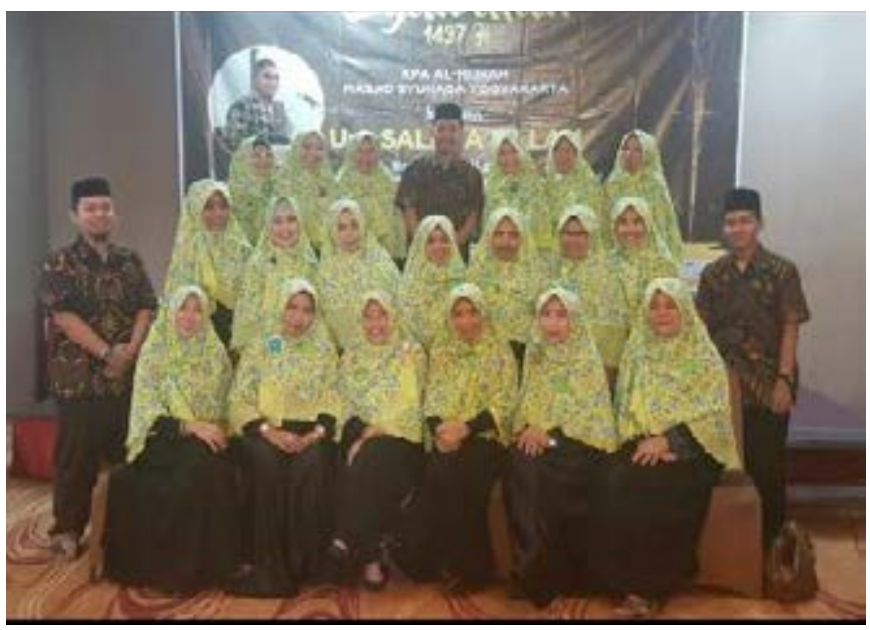

Gambar 19. Seragam Pengajian Al-Hijrah pada kesempatan yang lain

Seragam atau uniform adalah identitas yang paling mudah digunakan sebuah kelompok untuk meneguhkan kekuasaan. Penyeragaman merupakan salah satu bentuk artikulasi politik untuk menjelaskan jati diri institusi atau kelompok agar diterima dan memperoleh otoritas pada masyarakat. Pakaian menjadi alat komunikasi yang menampilkan identitas dalam diskursus tertentu (Hebdige, 1979: 204-205). 


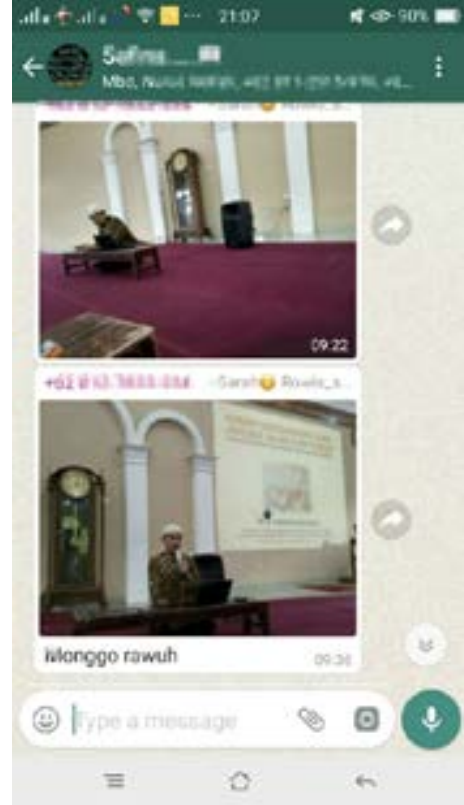

Gambar 20. Foto saat acara pengajian di bagikan di dalam WAG untuk mengajak anggota pengajian yang lain agar segera datang
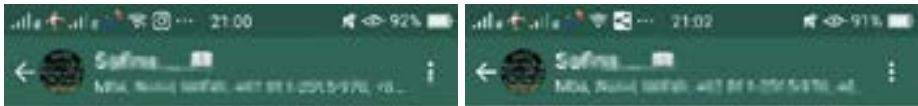

Tumbersusat

\section{BMBUN PAGI: 0}

- Jkalau sekiranya penduduk negert. negeri beriman dan bertakwa, pastilah Kami akan melimpahkan kepada mereka berkah dan langit dan burni. tetapi mereka mendustakan (ayatayat Kami) itu, maka Kami siksa mereka disebabikan perbuatannya". (QS. Al A'raaf: 96)

62.

Rasulullah shallallahu 'alaihi wa sallam berdoa.

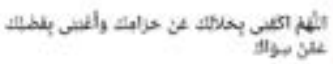

(Allahumak-firii bi halaalika 'an harocmik, wa agh-niniy bi fadhlika 'smman siwaek)
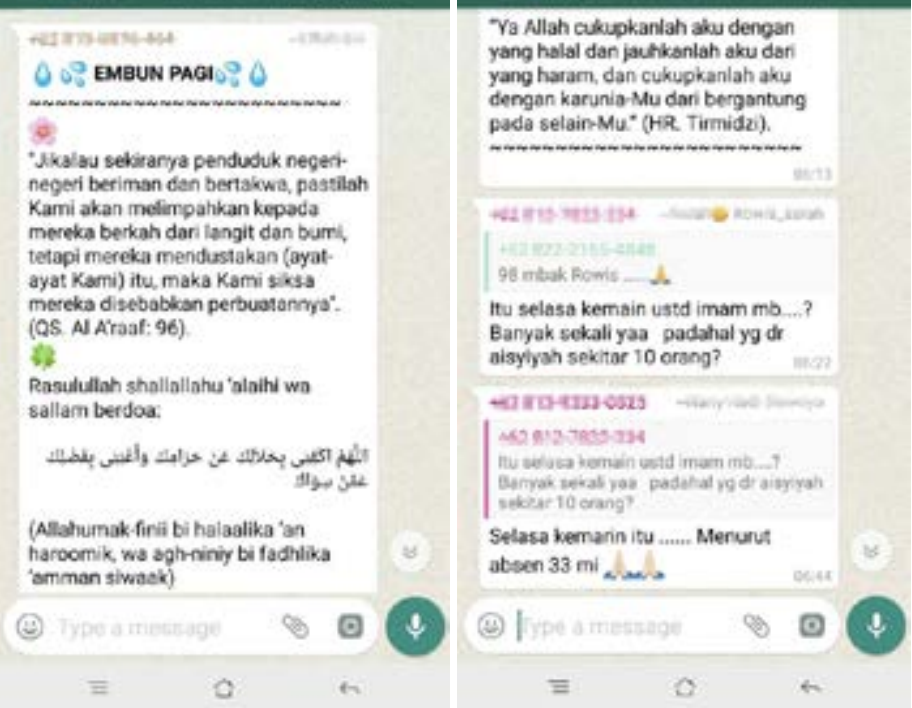

Gambar 21. anggota kelompok pengajian membagikan renungan "Islami" di dalam WAG pengajian Safina

Bentuk-bentuk ekspresi kesalehan yang lain dimanifestasikan melalui shodaqoh snack untuk pengajian, sumbangan untuk anak yatim, kegiatan saling mengingatkan sesama Muslim dengan berbagi motivasi-motivasi yang mencantumkan ayat suci Al-Quran dan Hadist di grup WAG masing-masing kelompok pengajian. Ekspresi kesalehan ini didukung kehadiran ustadz sebagai guru agama laki-laki yang hadir dalam hampir setiap pengajian, pengutipan sumber pesan dalam renungan-renungan, motivasi yang disebarkan dan direspon dalam perbincangan grup. Peneliti mengamati sangat jarang kelompok-kelompok keagamaan ini menghadirkan dan merujuk kepada ulama perempuan atau ustadzah.

Ekpresi lainnya yaitu ketika kelompok Medina membagi informasi mengenai pembukaan kelompok mengaji al-Quran secara bersama-sama di kota lain. Medina Yogyakarta merupakan cabang kelompok mengkhatamkan al-Quran yang berpusat di Jakarta. Maka pesan-pesan yang disampaikan oleh organisasi pusat dan cabang di kota lain juga terus dibagikan pada kelompok-kelompok di daerah. Gambar di atas menjadi bagian "aturan-aturan” yang ditetapkan 


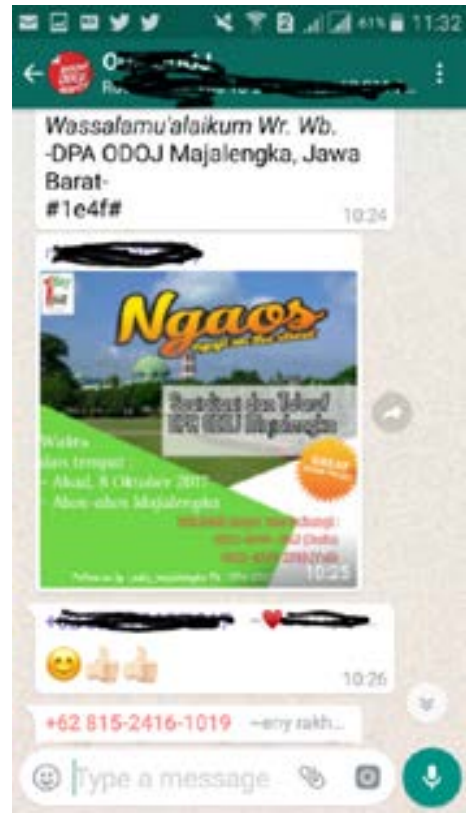

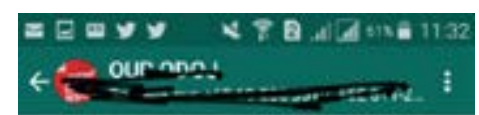

Format pendaftaran:

Nama_Grup ODOJ/Umum_No.

WA_Domisili

Contoh:

Sri_G3433 Kara

nganyar, Dawuan

Pendaftaran dan info lebih

lanjut dapat menghubungi

SMS/WA ke:

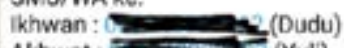

Akhwat:

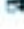

\section{Catatan:}

1. Berpakaian syar

2. Membawa Al Qur'an

3. Menyiapkan infak terbaik

4. Terbuka untuk Umum dan gratis

Jazakumullahu khairan katsiran

(4) liype a message o 6 (4)

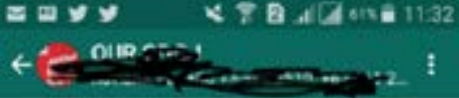

Kominex 0271/111/09/2017

Tanggal : 29 September 2017

Perihal : Ngaos

Tujuan : ODOJers dan Umum

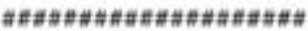

Assalamu'alaikum Wr. Wb.

DPA ODOJ Majalengka

mengundang ODOJers dan

Umum untuk hadir di acara

Ngaos (Ngaji on The Street)

dalam rangka sosialisasi DPA

ODOJ Majalengka.

in Syaa Allah dilaksanakan

pada:

Hari : : Ahad

Tanggal : 8 Oktober 2017

Pukul : 07.30 WiB-selesoi

Tempat : Area CFD Alun-alun

(C) Type a messane of 0

Gambar 22. Kelompok pengajian Medina membagi informasi mengenai acara membaca al-Quran bersama-sama

kelompok Medina dalam kegiatan-kegiatannya. Salah satu yang tertulis ialah peserta wajib untuk berpakaian syari'. Istilah syari' memang sedang hangat didengungkan oleh kelompok-kelompok Islam urban di Indonesia dalam kurun waktu lima tahun terakhir ini, meskipun akarnya sudah ada sejak didirikannya bank Muamalat sejak tahun 1991 (Juoro 2008). Menariknya penjelasan mengenai pakaian ini seolah hanya berlaku bagi Muslimah, namun tidak bagi Muslim yang mengikuti acara ini. Artinya laki-laki lebih bebas menggunakan pakaian apa saja, sedangkan tubuh perempuan masuk dalam kategori dan regulasi tertentu.

Produksi wacana kesalehan melalui pakaian dan tubuh perempuan menjadi bagian penting dalam artikulasi politik kelompok-kelompok pengajian kelas menengah Muslim. Karena mereka mampu membeli dan memenuhi standar pakaian ini maka bukan tidak mungkin, pakaian syari justru menjadi bagian dari peneguhan kelas sosial mereka. Syari' merujuk pada hukum sesuai tuntutan agama Islam. Meskipun interpretasi mengenai syari' sangat dapat diperdebatkan, namun dalam konteks diskursus Islam di Indonesia hal ini seakan sesuatu yang 
fix atau tidak dapat berubah. Gamis dan Hijab atau Khimar (lihat gambar 18) menjadi interpretasi tunggal dalam memaknai pakaian Muslimah yang sesuai hukum Islam, sehingga apabila ada perempuan yang tidak memakai pakaian seperti itu dianggap tidak syari' maka dianggap tidak sesuai dengan tuntutan agama Islam sehingga dampaknya ia tidak dapat dianggap "masuk" dalam kelompok pengajian tertentu.

Kualifikasi syari' merujuk pada pakaian yang menutupi seluruh tubuh perempuan yang biasa diwakili dengan pakaian gamis (rok terusan panjang) dan jilbab atau sekarang sedang tren dengan penyebutan hijab dan khimar yang menjuntai menutupi bagian dada dan pantat. Hijab sendiri berasal dari kata Arab hajaba yang berarti penutup, atau dalam kamus bahasa inggris ditemukan padanan kata ialah veil ${ }^{9}$. Hampir sama dengan hijab, khimar juga merujuk bahasa arab yang kurang lebih bermakna sama, peutup kepala, leher hingga dada. Masih menurut Guindi, hijab dan veil sesungguhnya tidak dapat dilekatkan pada pemaknaan identitas agama semata, melainkan persoalan simbol atas status perempuan mengenai pernikahan, salah satunya di masyarakat Mesir.

Persoalan yang muncul kemudian apabila gamis, hijab dan khimar "hanya" dimaknai dalam konteks pakaian dalam ruang publik yang berafiliasi pada indikator kesalehan, maka akan dengan mudah makna tersebut menjadi kabur, banal, dan dengan mudah digunakan sebagai bagian dari penguatan identitas kelas semata. Terbukti di Indonesia hal ini telah terjadi dengan tumbuh suburnya industri-industri fashion Islam yang penuh dengan label-label islami, syari', atau halal. Jamaah pengajian ibu-ibu menjadi salah satu ceruk pasar yang sangat menjanjikan seiring penguatan identitas Islam yang nampak nyata dalam pesan-pesan WAG pengajian kelas menengah Muslim.

\section{Kesimpulan}

Meminjam Almond \& Verba (1980) dalam konteks demokrasi terjadi tiga golongan yang sering muncul dalam situasi politik berbangsa dan bernegara, yaitu participants, subjects, parochial. Ketiga kelompok ini memiliki posisi masingmasing dalam dalam isu politik. Pertama pengetahuan kelompok yang terlibat aktif dalam proses politik. Kedua, masyarakat yang mau mematuhi mekanisme politik, namun memilih untuk menjaga jarak. Terakhir, ialah kelompokkelompokyang benar-benar tidak mau tahu mengenai situasi terkini dan berusaha untuk apolitis. Dalam konteks ini sebagaian besar kelompok WAG Medina

9 Guindi, Fadwa el. Jilbab: antara Kesalehan, Kesopanan, dan Perlawanan. Jakarta: Serambi. 2003. 
kota Yogyakarta memilih untuk bungkam dan menghindari percakapan politik, kondisi ini dapat dimaknai mereka berposisi sebagai subjects. Ciri ini memang cenderung dimiliki oleh kelas menengah dan kelompok perempuan. Berada pada kondisi yang mapan secara ekonomi dan sosial membuat kecenderungan kelas menengah untuk ingin "menyelamatkan" posisinya (Pambudy, 2012).

Demikian pula yang terjadi di grup pengajian Safina dan al-Hijrah, tidak ada pembahasan tentang dunia politik. Pembicaraan politik menjadi isu yang dianggap tidak akan banyak berhubungan dengan praktik kehidupan mereka sehari-hari. Sikap-sikap "netral” dianggap paling bijaksana untuk dapat masuk dalam segala lini kehidupan sosial dan kepentingan mereka di masyarakat. Bagi kelompok-kelompok ini dengan bersikap "netral" maka tidak akan memecah belah hubungan yang sudah mereka bina dan hal tersebut dianggapnya lebih menguatkan "ukhuwah Islamiyah". Meskipun pada praktiknya, sikap "netral" itu lebih dekat dengan suara arus utama. Perempuan kelas menengah Muslim terlihat lebih sigap dan heboh ketika menyikapi isu-isu yang seringkali sumber dan faktanya kabur, seperti isu komunisme, ketimbang memiliki perhatian yang intens terhadap kasus-kasus korupsi yang melanda sebagian elite politik di negeri ini. Hal ini dipicu karena budaya politik yang menjaga jarak dengan dunia politik. Perempuan yang semestinya menjadi kelompok yang melek politik tidak dijumpai, sebagaimana terjadi di Norwegia misalnya. Dampak dari perempuan yang melek politik menjadikan tata kelola pemerintahan menjadi lebih baik sebagaimana di negara-negara Skandinavia.

Situasi grup jamaah pengajian di pesan instan WhatsApp ini menggambarkan apa yang disebut sebagai masyarakat digital, yaitu ketika media informasi tanpa batas dalam genggaman tangan, namun penggunaan dan pemaknaan seringkali tidak berbanding lurus kemampuan literasi yang mereka miliki. Melalui gadget berharga ratusan ribu hingga jutaan rupiah individu dapat memproduksi dan mengkonsumsi pesan di grup WhatsApp sesuai dengan ketertarikan pada isu-isu tertentu, dan bahkan seringkali abai pada sebuah sumber beritanya. Konsekuensi logisnya yaitu apabila masyarakat Indonesia memiliki kemampuan melek media, melek internet, dan melek informasi maka tatanan kehidupan medianya akan makin menjanjikan kearah yang produktif dan inovatif. Tingginya kecakapan atas tiga hal ini akan mendorong meningkatnya keterbukaan dan tranparansi publik, daya pikir dan nalar kritis, hingga kemampuan ekonomi. 
Perubahan signifikan lainnya yaitu terjadi saat media baru dapat digunakan untuk memproduksi teks kreatif dan informatif. Masyarakat dapat mengakses informasi yang penting seperti pelayanan kesehatan, transportasi publik dan akses pendidikan secara gratis. Pemerintah dapat memaksimalkan kerja-kerja berbasis digital seperti e-government, e-budgeting dan e-commerce. Sehingga era disruption yang sedang terjadi saat ini semestinya dapat dimaksimalkan oleh komponen masyarakat sipil dengan memperbanyak aksi-aksi kolaborasi, berbagi peran (sharing) dalam bidang-bidang ekonomi, pengentasan kemiskinan, ketertinggalan informasi untuk menyebut beberapa contoh. Nampaknya perempuan kelas menengah Muslim perlu didorong lebih jauh untuk menjadi aktor perubahan sosial politik di era digital bagi kehidupan masyarakat sehingga terwujudnya civil Islam yang sebenar-benarnya dapat terealisir dengan segera, tanpa ada sikap mendua. Mengingat kemampuan dan modal yang dimiliki oleh kelompok tersebut sangat besar.

\section{Daftar Pustaka}

Chhatre, A. Political Articulation and Accountability in Decentralisation: Theory and Evidence from India. Dalam http://unpan1.un.org/intradoc/groups/ public/documents/apcity/unpan034369.pdf diakses pada 11 November 2017.

Cohavi, A. (2013). How did Whatsapp became the strongest social network? Calcalist. Retrieved from http://www.calcalist.co.il/local/ articles/0,7340,L-3593840,00.html

Fairclough, Norman. 1995. Media Discourse. Great Britain: Edward Arnold.

Gabriel A. Almond dan Sidney Verba. The Civic Culture Revisited: an Analitic Study. 1980. Boston: Little Brown.

Guindi, Fadwa el. Jilbab: antara Kesalehan, Kesopanan, dan Perlawanan. Jakarta: Serambi. 2003.

Hine, C. 2000, Virtual Ethnography, Sage, London.

Newman, N., and Levy, L.A.D. (2014). Reuters institute digital news report 2014: Tracking the future of news. Retrieved from http://reutersinstitute. politics.ox.ac.uk/sites/default/files/reuters\%20institute\%20 Digital\%20News\% 20Reports\%202014.pdf 
Newman, N., Levy, D.A.L., and Nielsen, R. K. (2015). Reuters institute digital news report 2015: Tracking the future of news. Reuters institute for the study of Journalism: University of Oxford.

Rheingold, Howard. 1995. The Virtual Community: Homesteading on the Electronic Frontier. Reading, MA: Addison-Wesley Pub.Co.

Sparks, C. (2001) 'The Internet and the Global Public Sphere', dalam L.W. Bennett and R.M. Entman (eds) Mediated Politics: Communication in the Future of Democracy. Cambridge: Cambridge University Press.

Tzuk, A. (2013). Whatsapp has 350 million active users a month. Calcalist. Retrieved October 23, 2015 from http://www.calcalist.co.il/internet/ articles/0,7340,L-3615097,00.html

Purbo, Ono W. dan Hartanto.(2002). E-Learning berbasis PHP dan MySQL, Penerbit Elex Media Komputindo, Jakarta.

Hefner, Robert W. 2001. Civil Islam: Islam dan Demokratisasi di Indonesia. Institut Studi Arus Informasi (ISAI) \& Asia Foundation: LKiS Yogyakarta.

Hebdige, Dick. 1997. Asal-usul Ideologi Subkultur Punk. Buku Baik: Yogyakarta. https://reutersinstitute.politics.ox.ac.uk/sites/default/files/Digital-NewsReport-2016.pdf

http://www.bbc.com/indonesia/trensosial-38204802 